\author{
Małgorzata OSIŃSKA \\ Uniwersytet Jagielloński \\ malgorzata.osinska@doctoral.uj.edu.pl
}

\title{
ZNACZENIE KOLEJNYCH LOKALIZACJI PRZYSTANI PROMÓW NA WYSPIE HONGKONG NA TLE PRZEMIAN SPOŁECZNYCH I KSZTAŁTOWANIA SIE LOKALNEJ TOŻSAMOŚCI
}

ABSTRACT The meaning of Piers' locations at Hong Kong Island in the background of social change and the process of shaping of local identity

The aim of this paper is to understand the meaning of the Star Ferry and Queen's Pier locations for the process of shaping Hong Kong identity and why unlike in previous similar cases, the latest removal of the Star Ferry and Queen's Pier met with resistance from Hong Kong citizens. Looking at Piers of the saga from the historical perspective, it is found that spatial practice of the pre-Second World War (WWII) piers was a mirror of a colonial and racially segregated city. The public space in the commercial heart of Hong Kong that housed the previous generations of piers was not accessible to the Chinese community, thus denying them rights to the city. It was only after WWII when the Government carried out further reclamation to meet the needs of an industrialising economy that inclusive public spaces were conceived in the commercial heart, enabling the general public to enjoy the city. Therefore when the Government decided to remove this very first public space in the political and economic heart of the city to conceive further reclamation for restructuring the economy, the citizens were determined to defend it. Piers were a physical and mental border of the two worlds, the edge of the city. With the social changes after WWII they were transformed into symbolic centres with a crucial meaning for shaping of the Hong Kong identity.

Key words: city, Hong Kong, identity, space

Słowa kluczowe: miasto, Hongkong, tożsamość, przestrzeń 


\section{WSTĘP. TOŻSAMOŚĆ MIESZKAŃCÓW A TOŻSAMOŚĆ MIASTA}

Hongkong to miasto, które z uwagi na swoją historię często bywa określane jako „pożyczone miejsce w pożyczonym czasie”. Przez ponad 150 lat stanowiło część Imperium Brytyjskiego, ale od prawie dwóch dekad ponad $7 \mathrm{mln}$ mieszkańców tego miasta znajduje się pod kontrolą Pekinu. Dzień 1 lipca 1997 roku, czyli dzień przekazania Hongkongu przez Brytyjczyków Chińskiej Republice Ludowej, stanowi dla mieszkańców Hongkongu jeden z najważniejszych punktów zwrotnych w historii tego miasta. Od tego momentu Hongkong, podobnie jak była portugalska kolonia Makau, która wróciła do Chin w 1999 roku, funkcjonuje bowiem jako Specjalny Region Administracyjny (SRA). Hongkong stanowi zatem część Chin, lecz w myśl zasady „jeden kraj, dwa systemy" przez 50 lat od momentu przekazania go Chinom ma zagwarantowany szeroki zakres autonomii, z wyłączeniem spraw obronności i polityki zagranicznej.

Hongkong można podzielić na trzy główne obszary kolejno włączane w skład Imperium Brytyjskiego, których skomplikowany status powstał w wyniku podpisywania przez Chiny tzw. nierównoprawnych traktatów. Pierwszy z nich, traktat nankiński kończący I wojną opiumową, z 29 sierpnia 1842 roku, dotyczył między innymi przekazania Wielkiej Brytanii przez Chiny wyspy Hongkong na własność. Następnie w 1860 roku podpisano pierwszą konwencję pekińską, na mocy której Królestwo Wielkiej Brytanii zyskiwało prawo „wiecznego użytkowania” półwyspu Kowloon. Warto zauważyć, że granica między Wielką Brytanią a Chinami na półwyspie Kowloon została w tamtym czasie ustalona w miejscu, gdzie obecnie przebiega ulica o takiej właśnie nazwie - Boundary Street. Dziś w zasadzie jest to środek miasta i w niczym, poza swą nazwą, nie przypomina bambusowego muru o wysokości $2,5 \mathrm{~m}$. W czerwcu 1898 roku doszło do podpisania drugiej konwencji pekińskiej, a najważniejszymi jej postanowieniami dotyczącymi Hongkongu było oddanie Wielkiej Brytanii w dzierżawę na okres 99 lat obszaru o nazwie Nowe Terytoria, w którego skład wchodziła część kontynentalna leżąca na północ od półwyspu Kowloon oraz 235 mniejszych wysp. Wyraźnie widać zatem podział całego terytorium Hongkongu na dwie części: tę, która została oddana Wielkiej Brytanii, a którą stanowiły wyspa Hongkong oraz półwysep Kowloon (do Boundary Street), oraz część, którą Chiny wydzierżawiały Brytyjczykom na okres 99 lat - tzw. Nowe Terytoria. Kwestia dzierżawy Nowych Terytoriów miała stać się w przyszłości pretekstem do podjęcia rozmów między Wielką Brytania a Chińską Republiką Ludową o przyszłości Hongkongu po 1 lipca 1997 roku (czyli po wygaśnięciu 99-letniej dzierżawy).

Równie interesująca co status formalny poszczególnych terytoriów wchodzących w skład Hongkongu jest też forma i wygląd samego miasta. Dla Europejczyka jawi się bardziej jako chaotyczna hybryda, pluralistyczna i otwarta, z wielością różnych perspektyw, aniżeli zunifikowana i uporządkowana całość. Brakuje jednego, dominującego nad resztą miasta centrum, ponieważ z uwagi na naturalny krajobraz idea centralizacji została tu zastąpiona przez nielinearny rozwój wielu współistniejących ośrodków. Swoim kształtem Hongkong nie przypomina również miast 
amerykańskich z ich niekończącymi się przedmieściami i wielopasmowymi autostradami. Trudno również doszukać się w nim podobieństw do chińskich miast położonych na kontynencie, i to zarówno biorąc pod uwagę ich historyczną formę, opartą na hierarchii i symetryczności, a także ściśle ustalone reguły planowania przestrzennego, jak i współczesne przemiany i transformację opartą początkowo na wzorcach sowieckich, a później coraz bardziej zwracające się ku zachodniemu modelowi współczesnego miasta.

W tym kontekście niezwykle interesująca wydaje się analiza kolejnych relokacji obu przystani promów łączących wyspę Hongkong z półwyspem Kowloon: Star Ferry oraz Queen's Pier. Artykuł ten jest próbą pokazania, że zmiany w lokalizacji obu przystani odzwierciedlają również transformacje zachodzące w społeczeństwie i proces kształtowania się lokalnej tożsamości wśród mieszkańców miasta. Hongkong to miasto na styku dwóch odmiennych tradycji, stąd tożsamość jego mieszkańców jest następstwem procesów mieszania się i łączenia kultur trwających od ponad stulecia. Losy obu przystani splatają się z przemianami społecznymi - szczególnie istotna jest tu Queen’s Pier, która najpierw była symbolem podziału społeczeństwa Hongkongu na klasę dominującą, reprezentowaną przez mniejszość brytyjską oraz nielicznych obywateli innych zachodnich państw, oraz na klasę podległą, czyli pozostałych mieszkańców Hongkongu, przybyłych głównie z Chin kontynentalnych. Następnie ta sama przystań po II wojnie światowej stała się symbolem uzyskania praw do miasta przez wszystkich jego mieszkańców. Z kolei współcześnie przystań Queen’s Pier zniknęła z mapy Hongkongu pod pretekstem dalszego procesu pozyskiwania gruntów z morza. Decyzja o jej likwidacji wywołała protesty rzeszy mieszkańców, którzy nie zgadzali się na zabranie im bardzo ważnej przestrzeni.

Na temat samych przystani powstało już kilka prac naukowych, między innymi praca magisterska „Central Star Ferry Pier: Policy, Politics and Protest in the Making of Heritage in Hong Kong” napisana przez Kim-wah Chaia z Uniwersytetu Hongkońskiego. Jednak skupia się ona na ukazaniu chronologii wydarzeń i tego, jak polityka władz miasta doprowadziła do uznania przystani Star Ferry za element dziedzictwa kulturowego Hongkongu, pomijając jednakże znaczącą rolę drugiej przystani, Queen's Pier. Ciekawą analizę praktyk i polityki przestrzennej wokół obu przystani z wykorzystaniem koncepcji przestrzeni Henriego Lefebvre'a przeprowadzili naukowcy z Wydziału Planowania Przestrzennego na Uniwersytecie Hongkońskim w artykule Spatial Practice, Conceived Space and Lived Space: Hong Kong's "Piers Saga” through the Lefeburian Lens. W ostatnich miesiącach seria artykułów prasowych w dzienniku "South China Morning Post" (SCMP) o tym, w którym miejscu rząd hongkoński powinien zrekonstruować Queen's Pier, ponownie podniosła temat znaczenia przestrzeni wokół obu przystani promowych.

Badając zmiany lokalizacji w kontekście budowania własnej tożsamości, posłużę się perspektywą historyczną, a także koncepcją architektury i przestrzeni zniknięcia, szerzej opisaną przez Ackbara Abbasa, który jednakże w swoim eseju skupia się głównie na kompleksowej analizie formy, ukazując generalny obraz współczesnego Hongkongu z jego historyczno-, kulturowo- i postkolonialną sytuacją globalnej metropolii. 
Tożsamość jest definiowana jako obraz nas samych w relacji do „znaczących innych”, których obecność również ma wpływ na proces konstruowania się tożsamości ${ }^{1}$. W przypadku Hongkongu „znaczącym innym” była początkowo Wielka Brytania, a następnie komunistyczne Chiny. Relacje władzy pomiędzy swoimi i obcymi odnoszą się zarówno do aspektu politycznego, jak i ekonomicznego. Kwestia tego, kto odgrywa dominującą rolę, ma wpływ na układ sił, a przez to również na konstruowanie tożsamości. W obliczu tych relacji tożsamość może także generować działania zbiorowości w imię walki o wspólne wartości, zaangażowanie wspólnoty z kolei również wpływa na konstruowanie tożsamości - mamy tu do czynienia z relacją wzajemności.

W przypadku tożsamości zbiorowych istotne znaczenie mają wartości. Stanowią one przejaw panujących w danej wspólnocie relacji, odnoszących się w jednakowym stopniu do kategorii przestrzenno-symbolicznych oraz interakcji pomiędzy grupami społecznymi na danej przestrzeni: Ludzie wytwarzaja swoja przestrzeń, ksztattując określone jej formy, które maja zarówno funkcje i znaczenia ${ }^{2}$. Wartości pozwalają odróżniać elementy istotne i ważne od zwyczajnych dla danej wspólnoty. Miasta - zdaniem Aleksandra Wallisa - są wielkim siedliskiem symboli ${ }^{3}$.

Jednym z pierwszych badaczy, który zwrócił uwagę na symboliczne znaczenie przestrzeni był Florian Znaniecki. Przestrzeń jest nacechowana wartościami stanowiącymi element ogólniejszego systemu wartości i dopiero w stosunku do niego zyskuje znaczenie. Wartość przestrzeni - pisze Znaniecki - jest sktadnikiem jakiegoś nieprzestrzennego systemu wartości, wodniesieniu do którego posiada swoistą treść i znaczenie $e^{4}$.

Tak rozumiana przestrzeń symboliczna - zdaniem Bohdana Jałowieckiego - stwarza możliwość trojakiego rodzaju działań dla jednostek i grup ludzkich. Są to: praktyki przestrzenne, które prowadzą do wytwarzania przestrzeni; naznaczanie przestrzeni, czyli nadawanie znaczenia; ostatnim zaś rodzajem działań jest proces przyswajania przestrzeni, w którego wyniku ludzie adaptują się do istniejącej przestrzeni, jak również przestrzeń adaptują do swoich potrzeb zgodnie z własnymi wartościami i przekonaniamis. Celowość badań nad tożsamościami zbiorowymi trafnie opisuje Zbigniew Bokszański, pisząc, że odnosząc się do pojęcia tożsamości zbiorowych, możemy podejmować próby wyjaśnienia zjawisk społecznych, jak również opisywać efekty procesów zmian społecznych ${ }^{6}$.

Warto również pamiętać, że azjatyckie formy kształtowania się własnych tożsamości oraz wszelkich form powstawania narodów stanowią poważne wyzwanie dla prób generalizacji, dlatego każdy przypadek warto rozpatrywać z osobna, uwzględniając

J. Turner, P. Oakes, The Significance of the Social Identity Concept for Social Psychology with Reference to Individualism, Interactionism and Social Influence, „British Journal of Social Psychology” 1986, Vol. 25, nr 3, s. 237-252, [online] http://dx.doi.org/10.1111/j.2044-8309.1986.tb00732.x.

2 B. Jałowiecki, Spoteczne wytwarzanie przestrzeni, Warszawa 1988, s. 11-39, 249-255.

3 A. Wallis, Socjologia wielkiego miasta, Warszawa 1967, s. 76, Omega, 69.

4 F. Znaniecki, Socjologiczne podstawy ekonomii ludzkiej, „Ruch Prawniczy, Ekonomiczny i Socjologiczny" 1938, nr 1, s. 91-94.

$5 \quad$ B. Jałowiecki, Spoteczne..., s. 11-39, 249-255.

6 Z. Bokszański, Tożsamości zbiorowe, Warszawa 2005, s. 55-56. 
jego lokalny kontekst i specyfikę. Nie inaczej jest w przypadku Hongkongu. Ackbar Abbas, pisząc o tym mieście, zwraca uwagę na problem tożsamości i kultury przedstawiony w opozycji do miasta, którego historia oparta jest na zapożyczeniach i nieustających zmianach: Historyczna wyobraźnia, wiara obywatelska, które moga przyczynić się do ksztaltowania wtasnej historii, sa zastępowane przez spekulacje na rynku nieruchomości albo przez obsesję na punkcie mody i konsumpcjonizmu ${ }^{8}$.

Abbas odnotowuje również, że architektura jest zawsze gdzieś, zawsze w jakimś miejscu, stąd jest pierwszym rzucającym się w oczy dowodem domniemanej tożsamości miasta-miejsca. Patrząc chociażby na dzielnicę Central, widać wyraźnie, że Hongkong to miasto, które zmienia swoje oblicze co kilka dekad poprzez kolejne fazy procesu odzyskiwania gruntu, które całkowicie przeobrażają kształt północnego wybrzeża wyspy Hongkong.

To miasto doprowadziło do ekstremum argument wysuwany przez Sharon Zukin o tym, że to rynek (w sensie ekonomicznym) kształtuje miejsce9. Kombinacja ograniczonej warunkami geograficznymi przestrzeni, a co za tym idzie wysokich cen poszczególnych działek, spekulacji rynkowych, a także obecność wielu dużych korporacji walczących o najlepszą i najbardziej prestiżową przestrzeń powoduje konieczność ciągłej przebudowy i czyni to miasto subtelnie nierozpoznawalnym. Zmiany bywają dość gwałtowne i zaskakujące. Możemy tu zatem mówić o dwojakim charakterze społecznego wytwarzania przestrzeni - planowym i żywiołowym, o czym pisze Marek Szczepański: Wytwarzanie przestrzeni miejskiej nie ma charakteru przypadkowego i dowolnego. Istnieje bowiem wiele determinant tego procesu oraz czynników go regulujacych. [...] Identyfikacja kluczowych determinant spotecznego wytwarzania przestrzeni nie oznacza bynajmniej, iż proces ten ma w petni planowy i kontrolowany charakter. Wydaje się, że każde miasto jest rezultatem zarówno procesów planowych, jak żywiotowych i spontanicznych ${ }^{10}$.

Abbas stawia również ważne pytanie: na ile i czy w ogóle architektura może reprezentować miasto? Podobnie jak zauważa Diana Agrest, jedną rzeczą jest oglądanie miasta przez pryzmat architektury, a drugą oglądanie architektury przez pryzmat miasta ${ }^{11}$. Jak dotąd architektura w Hongkongu jest głównym czynnikiem wzmacniającym to, co można nazwać przestrzenią kolonialną, rozumianą jako projekcja pewnej wizji, która byłaby utrwalonym zapisem pewnego symbolicznego porządku. Abbas zwraca uwagę na to, że sformułowanie problemów, z którymi trzeba poradzić sobie w obrębie danej przestrzeni, jest w zasadzie kluczową sprawą, szczególnie w przypadku Hongkongu, gdzie przestrzeń kolonialna jest przestrzenią znikającą.

A.W. Jelonek, Wielokulturowość, separatyzm i budowa państwa narodowego w Tajlandii, Kraków 2011, s. 33 .

8 A. Abbas, Hong Kong. Culture and the Politics of Disappearance, Minneapolis 1997, s. 5, Public Worlds, 2.

9 S. Zukin, Postmodern Urban Landscapes: Mapping Culture and Power, [w:] Modernity and Identity, red. S. Lash, J. Friedman, Oxford 1992.

10 M. Szczepański, „Miasto socjalistyczne” i świat spoteczny jego mieszkańców, Warszawa 1991, s. 15-22, Rozwój Regionalny, Rozwój Lokalny, Samorząd Terytorialny, 32.

11 D.I. Agrest, Architecture from Without. Theoretical Framings for a Critical Practice, Cambridge (Mass.) 1993, s. 137. 
Hongkong jest jednak miastem szczególnym, gdyż proces znikania przestrzeni nie oznacza dosłownej likwidacji i całkowitego zniknięcia, a raczej ma wiele wspólnego $\mathrm{z}$ nieustanną obecnością i zmianą ${ }^{12}$. Okazuje się, że nawet wyburzenie jakiegoś budynku czy likwidacja pewnej przestrzeni wcale nie powoduje jej całkowitego wymazania z mapy pamięci. W przypadku Hongkongu i przestrzeni oraz formy miasta nie bez znaczenia jest również fakt, że Hongkong znalazł się niejako w potrzasku pomiędzy dwoma znaczącymi mocarstwami: Wielką Brytanią i Chinami. To w zasadzie determinuje potrzebę uchwycenia obrazów tożsamości oraz konieczności zdefiniowania przestrzeni miasta poprzez konkretne budynki i znaczenia.

Wzajemna relacja pomiędzy przestrzenią a miejscem jeszcze komplikuje te dociekania. Tych dwóch pojęć nie sposób ani całkowicie sobie przeciwstawić, ani też rozpatrywać osobno, ponieważ trudno wyobrazić sobie rozważania o czysto fizycznym miejscu bez kontekstu przestrzennego i tego, jak np. nowe technologie i informacje wpływają na zmianę fizycznych aspektów i formy miejsca. Przestrzeń bowiem jest rozpatrywana w kontekście odczuwania i zmysłów, a nie w kontekście fizycznym, jest zdematerializowana.

Paul Virilio zauważa, że nowe technologie doprowadziły do zakwestionowania tego, co dotychczas uważaliśmy za granice miast. Zamiast tego pojawił się nowy twór interfejs miasta ${ }^{13}$. W przypadku takiego miasta jak Hongkong granica z Chinami może być naruszana praktycznie w każdym miejscu (fizycznie), co zawsze dawało się odczuć w trakcie napływu kolejnych fal imigrantów zmierzających do Hongkongu w czasie niepokojów społecznych na kontynencie. Dodatkowo, za sprawą Brytyjczyków, Hongkong został włączony w wirtualną sieć globalnych połączeń, co dewaluuje koncept fizyczności miejsca i przestrzeni. Mowa tu o przestrzeni globalnej, co do której natury trafnie wypowiedział się Manuel Castells: Rewolucja technologiczna, skoncentrowana wokót technik informacyjnych, przeobrazita $z$ dużym przyspieszeniem materialne podstawy spoteczeństwa. Gospodarki na catym świecie zaczęty stawać się globalnie wspótzależne, wprowadzając nowa formę związków między ekonomia, państwem i spoteczeństwem, $w$ systemie o zmiennej geometrii ${ }^{14}$.

Innymi słowy, jest całe spektrum przestrzennych i historycznych zapożyczeń, które należałoby wyróżnić, to z kolei pozostawia przestrzeń do dyskusji na temat polityki przestrzennej, nawet jeśli będziemy ją rozumieć podobnie jak Abbas, czyli jako proces znikania. Architektura nie może bowiem zostać oddzielona od kontekstu, w którym powstaje, zarówno ideologicznego, jak i fizycznego, przestrzennego. Abbas argumentuje, że Hongkong w tym wypadku jest szczególnym przypadkiem architektury kolonialnej, którą on nazwał przestrzenią zniknięcia.

Przestrzeń, która stanowi również miejsce interakcji dla wspólnoty, jest też jednym ze składników tożsamości. Przestrzeń jest jednym z elementów pozwalających

12 Tamże, s. 65.

13 P. Virilio, Lost Dimension, New York 1991, s. 31, Semiotext(e) Foreign Agents Series.

14 M. Castells, Spoteczeństwo sieci, przeł. M. Marody i in., red. nauk. tenże, Warszawa 2008, s. 19, Wiek Informacji, 1. 
dokonywać jednostce i zbiorowości nieustannej identyfikacji w oparciu o stałe składniki w zmieniającej się rzeczywistości. Obecność miejsc symbolicznych w przestrzeni ma charakter szczególny dla kształtowania się tożsamości danej zbiorowości: Konstruowanie tożsamości miasta polega $w$ znacznej mierze na ksztattowaniu, selekcjonowaniu, pielegnowaniu i propagowaniu dziedzictwa historycznego ${ }^{15}$. Wydaje się, że w przypadku Hongkongu to nieobecność i zniknięcie tych miejsc symbolicznych mają znaczenie dla wspólnoty i przestrzeń, której nie ma, istnieje w pamięci zbiorowej tego społeczeństwa, przez co nabiera szczególnej wartości - nadaje i tworzy sens tożsamości.

W rozważaniach o tożsamości i przestrzeni nie sposób również nie wspomnieć znaczenia granic. Zgodnie z tym, co pisze Fredrik Barth ${ }^{16}$, granice istnieją niezależnie od przepływu ludności między nimi, gdyż ich istnienie nie zależy od braku kontaktów i przepływu informacji, a powiązane jest z kategoryzacją społeczną oraz procesem ekskluzji i inkluzji. Granice stanowią również instytucjonalizacje kontaktów społecznych, budowanych pomiędzy dwoma odrębnymi grupami pomimo istnienia granic. Dla kształtowania się tożsamości znaczące są symboliczne centra, przestrzenie zbiorowej pamięci i miejsca-pomniki, to granice jednak artykułują podziały na swoich i obcych, pomagając tym samym porządkować społeczny obraz świata. Gdzie zatem przebiega symboliczna granica tożsamości Hongkończyków, która definiuje ich samych?

Pomimo gwałtownych zmian zarówno w polityce, jak i gospodarce proces wyłaniania się własnej tożsamości Hongkongu przebiegał zdecydowanie w wolniejszym tempie. Przez dziesięciolecia rodziny Chińczyków przybyłych do Hongkongu żyły w mieście, korzystając z jego przestrzeni i możliwości, krok po kroku konstruując rosnącą i wyedukowaną klasę średnią, której polityczne i ekonomiczne zainteresowania przybrały na sile w latach 90. XX wieku. W 1996 roku, otwierając wystawę Hong Kong Sixties: Design Identity, Matthew Turner, dyrektor Hong Kong Art Centre, zapytał:Jeśli naszym ojcem jest brytyjskość, a matką chińskość, kim jesteśmy? W publikacji towarzyszącej tej wystawie Turner słusznie zauważył: $Z$ punktu widzenia prawa międzynarodowego jest oczywiste, że Hongkończycy sa „ludźmi”. Ale tożsamośc, która może być posiadana, może też być zabrana [...]. W końcu, tożsamość kulturowa, jak demokracja, nie może być podana przez prawników, polityków czy profesorów - musi zostaćstworzona ${ }^{17}$. W swoich poszukiwaniach Turner skłania się do ujęcia tożsamości w ramy stylu życia, który jest bądź co bądź nie tak upolitycznionym konceptem, ponieważ styl może być wyrażony, ale nie można go łatwo ocenzurować.

Należy podkreślić, że Turner, podobnie jak wielu innych badaczy, postrzega różnicę między kontynentem a Hongkongiem jako część procesu tworzenia się własnej tożsamości. Hongkończycy, którzy przybyli do Hongkongu z Chin w latach 70., mieli luźniejsze powiązania z Chinami, chociażby dlatego, że już w Hongkongu uzyskali dobre

15 O Krakowie raz jeszcze. Szkice do portretu miasta, red. K. Frysztacki, Z. Mach, Kraków 2008, s. 9.

16 Ethnic Groups and Boundaries. The Social Organization of Culture Difference, red. F. Barth, Illinois 1969, s. 9-10.

17 M. Turner, 60s/90s, [w:] Hong Kong Sixties. Designing Identity, red. tenże, I. Ngan, Hong Kong 1996, s. 31 . 
wykształcenie z językiem angielskim jako podstawowym. W noc przejęcia Hongkongu przez Chiny Siu Fung Han, dziennikarz gazety „Ming Pao”, tak podsumował, kim jest elita, która dojrzewała w latach 70.: To pokolenie Hongkończyków [...] niepostrzega siebie jako majacych niekwestionowane emocjonalne więzi z Chinami. Jednakże chce zrozumieć Chiny z oświeconej perspektywy, aby pomóc Chinom w rozwoju, dzięki czemu Chiny bytyby częścia świata [...]. Jeśli to pokolenie dostanie konieczne miejsce, to wprowadzi świat przez Hongkong do Chin, pomagajac Chinom wejsć w XXI w. z dumą ${ }^{18}$.

$\mathrm{Z}$ powyższych słów można wysnuć wniosek, że Hongkończycy owszem, są Chińczykami, ale niechińskimi Chińczykami. Nawet w jednym z ówczesnych seriali Chińczycy z kontynentu zostali przedstawieni jako gtupi, $z$ niskimi zdolnościami analitycznymi, zacofani i biedni, Hongkończycy natomiast jako bystrzy, zdolni, wyedukowani i nowocześn $i^{19}$. Takie rozróżnienie na Chińczyków z kontynentu i tych z Hongkongu jest oczywiście wynikiem procesów natury politycznej i społecznej, które mają na celu stworzenie wyraźnych barier pomiędzy tymi dwiema chińskimi przestrzeniami, wyolbrzymionymi jeszcze przez różnice ekonomiczne i polityczne.

W Hongkongu możemy zatem mówić o dwóch zasadniczych wymiarach tożsamości. Po pierwsze jest to tożsamość konstruowana w odniesieniu do znaczącego innego, którym w przeszłości była Wielka Brytania, a którym po 1997 roku stały się Chiny (nie można jednak przy tym zapomnieć, że dużą rolę ciągle odgrywa tu dziedzictwo pozostawione przez Brytyjczyków). Drugim wymiarem tożsamości Hongkongu jest fizyczna przestrzeń tego miasta - jej ograniczenia wynikające z ukształtowania terenu i pokonywanie tych naturalnych przeszkód przez mieszkańców w zależności od stopnia rozwoju cywilizacyjnego i technicznych możliwości w danym czasie. Tożsamość stanowi zatem formę dialogu pomiędzy mieszańcami a „znaczącym innym” oraz fizyczną przestrzeń stanowiącą bariery zarówno w wymiarze rzeczywistym i fizycznym, jak i psychologicznym. Stąd przystanie promów Star Ferry i Queen’s Pier zlokalizowane na północnym brzegu wyspy Hongkong, czyli dawniej na samym krańcu miasta, były nie tylko łącznikiem między wyspą i półwyspem Kowloon, ale stanowiły też punkt wyjścia do dalszego rozwoju i poszerzania granic miasta. Ich lokalizacja odzwierciedlała kraniec fizycznych ram miasta reprezentujących symboliczne znaczenia.

\section{HISTORYCZNE LOKALIZACJE I ZNACZENIA PRZYSTANI STAR FERRY ORAZ QUEEN'S PIER}

$\mathrm{Z}$ uwagi na topograficzne ograniczenia stanowiące fizyczne granice i psychologiczne bariery, głównym źródłem produkcji przestrzeni w Hongkongu jest jej odzyskiwanie z morza. Kolejne fazy tego procesu u wybrzeży północnej części wyspy Hongkong na

18 G. McDonogh, C. Wong, Global Hong Kong, New York-London 2005, s. 114.

19 Mam tu na myśli serial z lat 70. XX wieku, którego głównym bohaterem jest tytułowy Ah-Chan, imigrant z Chin kontynentalnych. Ah-Chan i cechy, które posiadał, w oczach Hongkończyków stał się synonimem Chińczyka z kontynentu - innego niż oni sami. Podobnie zauważa Ma Kit-Wai, a także Gary McDonogh oraz Cindy Wong. G. McDonogh, C. Wong, Global..., s. 114. 
wysokości dzielnicy Central oraz Wan Chai (w latach 1841-2009) doprowadziły do wielokrotnej relokacji przystani promowej, a także całkowitej zmiany wyglądu wybrzeża (rys. 1).

Rys. 1. Cztery fazy odzyskiwania przestrzeni na granicy dzielnic Central i Wan Chai wraz z zaznaczoną relokacją przystani promów Star Ferry (numery 1, 2, 3, 4) oraz pierwszej i drugiej generacji Przystani Królewskiej - Queen’s Pier (litery A oraz B)

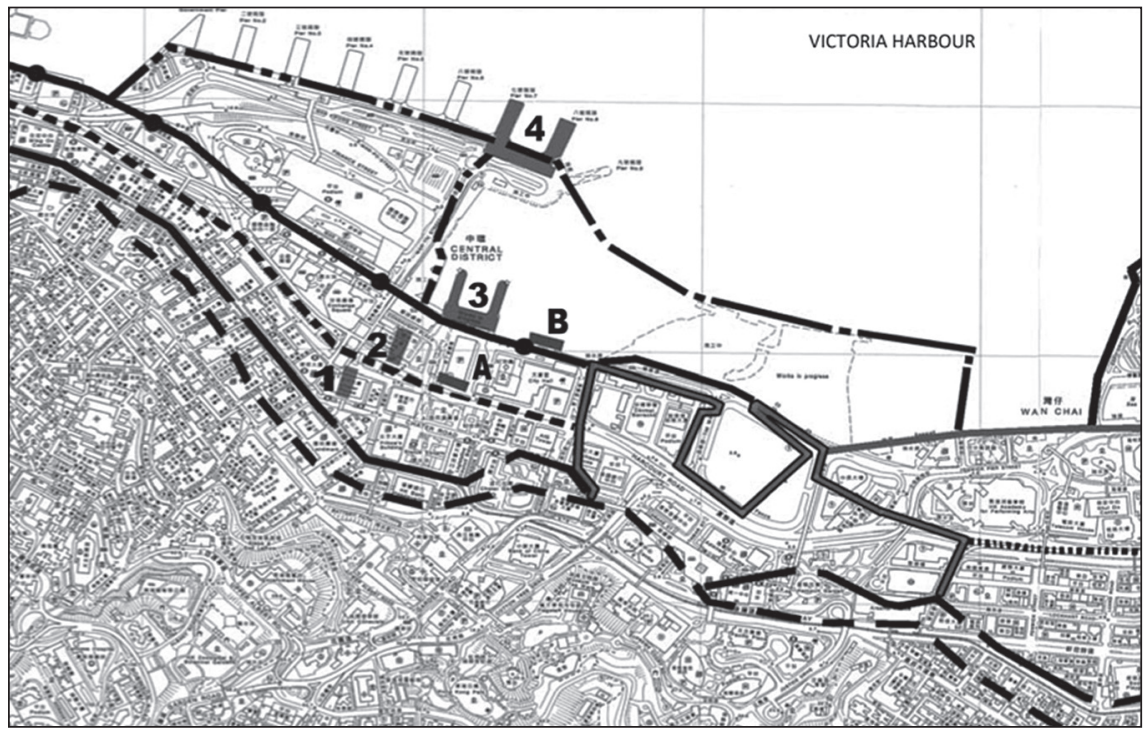

Źródło: M.K. Ng i in., Spatial Practice, Conceived Space and Lived Space: Hong Kong's „Piers Saga” through the Lefeburian Lens, „Planning Perspectives” 2010, Vol. 25, nr 4, s. 412, [online] http://dx.doi.org/10.10 $80 / 02665433.2010 .505060$.

Lokalizacja przystani dla promów Star Ferry jest wynikiem wyburzenia poprzedniej, z 1957 roku. Nowa przystań została wybudowana w sąsiedztwie miejsca, gdzie stała poprzednia, która z kolei była następczynią przystani drugiej generacji wybudowanej w 1911 roku. W przeciwieństwie jednak do wszystkich poprzednich zmian w lokalizacji przystani ta ostatnia spotkała się z silnym sprzeciwem ze strony społeczeństwa i protestami organizowanymi przez różne grupy społeczno-kulturowe. Stało się tak, ponieważ w przekonaniu mieszkańców została im odebrana przestrzeń społeczna, z która wiązało się wiele znaczeń i wspomnień ważnych z punktu widzenia pamięci zbiorowej lokalnej wspólnoty. Hongkończycy doskonale zdawali sobie sprawę z tego, że po raz kolejny odbierane jest im coś więcej niż tylko fizyczna przestrzeń i bryła budynku. W zamian stworzono miejsce pod infrastrukturę drogową oraz przestrzeń dla nowych galerii handlowych - co wpisuje się całkowicie w stosowaną od początku retorykę lokalnych władz przy przeprowadzaniu procesów odzyskiwania gruntów i zmian w przestrzeni. Zarówno Brytyjczycy, jak i obecni rządzący Hongkongiem zawsze usprawiedliwiają te projekty próbą rozładowania i tak już wysokiej gęstości zaludnienia w tym obszarze i zawsze kończy się na budowaniu nowych dróg i budynków, które potem służą jako 
siedziby największym bankom lub też są instytucjami lokalnej władzy albo budynkami komercyjnymi. W znikomym stopniu nowa przestrzeń rzeczywiście tworzona jest z myślą o mieszkańcach i im udostępniana. Prześledzenie historii tego miejsca pozwala zatem nie tylko zobaczyć, jak przebiegał podział ówczesnego społeczeństwa Hongkongu, lecz również pokazać zmiany, które doprowadziły do zniesienia tego podziału i wytworzyły tak silne przywiązanie wśród dzisiejszych Hongkończyków do przestrzeni związanej z przystaniami.

Początki przystani promowej sięgają lat 70. XIX wieku. Pierwsza generacja połączenia promowego została zainicjowana pod nazwą Morning Star przez odnoszącego biznesowe sukcesy właściciela kilku hoteli, piekarni i firmy kateringowej - Dorabjee Nowrojee. Zdaniem historyków powodem otwarcia regularnego połączenia między obiema częściami Hongkongu przez Nowrojee była przede wszystkim chęć dostarczania swoich wypieków również na półwysep Kowloon (przyłączony do terytorium Hongkongu zaledwie 10 lat wcześniej w 1860 roku), a także możliwość urządzania rejsów z rodziną i przyjaciółmi. Regularne kursy promów Morning Star między Pedder’s Wharf (wyspa Hongkong) a Kowloon Point (półwysep Kowloon) zostały zapoczątkowane w następnym dziesięcioleciu. Półwysep Kowloon liczył sobie w tamtych czasach mniej niż 8000 mieszkańców, możliwości biznesowe otworzyły się dopiero wraz z utworzeniem w 1886 roku przedsiębiorstwa Kowloon Wharf, zajmującego się obsługą nabrzeża wtedy to promy należące do Nowrojee oferowały swoje usługi pracownikom Kowloon Whorf, a później również zwykłym mieszkańcom Hongkongu. W 1898 roku Nowrojee sprzedał swoje promy firmie Star Ferry Company Limited, która w związku z zakończeniem procesu odzyskiwania gruntów (Praya Reclamation Scheme) w 1905 roku została zmuszona do budowy nowej przystani, zgodnie z nowo wytyczoną linią brzegową i planami zagospodarowania przestrzennego. Budowa przystani drugiej generacji została ukończona w 1910 roku. Nowy budynek znajdował się przy Ice House Street, w miejscu dzisiejszego Jardine House. Przed II wojną światową przystań Star Ferry stanowiła głównie punkt tranzytowy, położoną w samym sercu miasta „przestrzeń pomiędzy" - między Europą a Chinami.

W zasadzie przystań była tylko punktem służącym do przemieszczania się całej masy ludzi, których domy były przecież w zupełnie odmiennych częściach świata, a którzy spotkali się w Hongkongu i nawet tu ich codzienne praktyki społeczne odbywały się w niemal zupełnej izolacji. Na przełomie XIX i XX wieku istniały trzy klasy dla pasażerów korzystających z usług Star Ferry. Co istotne, Europejczycy nie mogli podróżować klasą trzecią. Był to oczywisty przejaw dyskryminacji i podziału społecznego istniejącego wówczas w Hongkongu. Po drugie, historia przystani Star Ferry i późniejszej Queen's Pier jest istotnym przykładem segregacji rasowej w obrębie przestrzeni publicznej, gdyż obie przystanie znajdowały się dosłownie na styku dwóch przestrzeni, a tym samym dwóch społeczności: brytyjskich kolonizatorów i ludności pochodzenia chińskiego.

W 1925 roku w najbliższym sąsiedztwie przystani Star Ferry wybudowano pierwszą generację tzw. Przystani Królewskiej - Queen’s Pier. Na początku lat 20. XX wieku podjęto decyzję o zastąpieniu drewnianej konstrukcji bardziej trwałą - betonową. Konstrukcja przystani została ukończona w lutym 1923 roku, całość oddano do użytku 
w 1925 roku, rok wcześniej zmieniając nazwę ze Statue Pier na Queen’s Pier, na cześć królowej Wiktorii. Była to przystań obsługująca jedynie polityków i ówczesnych dygnitarzy, używana również przy okazji różnych ceremonii i świąt oficjalnych. Zatem zupełnie inna od przystani Star Ferry, którą podróżowali zwykli mieszkańcy Hongkongu. Pierwszym pasażerem Queen's Pier był odchodzący gubernator ówczesnego Hongkongu, sir Reginald Stubbs, który z tej właśnie przystani odpłynął po zakończeniu swojej kadencji. Jego następca, sir Cecil Clementi, był jednocześnie pierwszym dostojnikiem, który przypłynął promem do Queen’s Pier.

Omawiając rolę przystani Queen’s Pier, należy również wspomnieć o istotnej roli, jaką odgrywała przy tych wszystkich oficjalnych uroczystościach dopiero co wybudowana Connaught Road, biegnąca wzdłuż nowej linii nabrzeża. Była najbardziej rozpoznawalną ulicą ówczesnego Hongkongu, z wieloma ważnymi, reprezentatywnymi budynkami rządowymi i komercyjnymi. Dodatkowo, tuż za przystanią Queen’s Pier (patrząc od strony portu) zaprojektowano Statue Square, który był pomyślany jako ogromna otwarta przestrzeń zaplanowana z myślą o nowym biznesowym centrum miasta, niebędąca jednak dostępną dla przeciętnych mieszkańców. Projekt był efektem współpracy rządu Hongkongu z Hongkong Bank, który w 1895 roku miał otrzymać gwarancję dzierżawy od Korony dwóch działek znajdujących się przed budynkiem głównej siedziby banku (il. 2) na 999 lat ${ }^{20}$.

W 1901 roku ówczesny rząd Hongkongu zwrócił się do Departamentu Zarządzania Banku z zawiadomieniem o swojej trosce i chęci zachowania najbliższego sąsiedztwa wokół Pomnika Królowej (Queen’s Statue) jako przestrzeni otwartej. Zaproponowano wówczas, że cztery działki wokół pomnika będą zaprojektowane jako tereny zielone, tzw. zielone serce (ang. green heart) miasta. Bank zgodził się z tą koncepcją rządową. W 1934 roku Hongkong Bank wydzierżawił działkę w bezpośrednim sąsiedztwie swojej kwatery (po wschodniej stronie) w miejscu opuszczonej siedziby należącej do City Hall, dzięki czemu mógł powiększyć swoją siedzibę, co stało się rok później. W 1935 roku zielone tereny wokół pomnika i przed siedzibą banku nie były zaprojektowane w sposób umożliwiający swobodne korzystanie z tej przestrzeni mieszkańcom Hongkongu. Trawniki krótko przycięte w ornamentalne wzory oraz poręcze skutecznie blokowały dostęp do tej przestrzeni przechodniom (dopiero po II wojnie światowej, w 1947 roku, usunięto poręcze). Przestrzeń, która przez władze postrzegana była jako otwarta, w rzeczywistości wcale taka nie była.

Ówczesna przystań Queen's Pier oraz Statue Square są dobrymi przykładami tego, jak architektura i przestrzeń mogą tworzyć nowe lub wspierać istniejące podziały społeczne. Istotna zmiana nastąpiła dopiero w połowie lat 50 . XX wieku, kiedy to w związku z zakończeniem kolejnego projektu odzyskania gruntów wzdłuż nabrzeża na wyspie Hongkong przeniesiono przystań kilkadziesiąt metrów dalej, na krawędź nowej linii brzegowej wyznaczonej ukończeniem kolejnej fazy pozyskiwania gruntów (28 czerwca 1954 roku). Stara przystań (służąca tylko do oficjalnych celów i uroczystości) została

20 I. Lambot, G. Chambers, One Queen's Road Central, Hong Kong 1986, za: A. Walker, Hong Kong. The Contractors' Experience, Hong Kong 1995, s. 3. 
zburzona około pół roku później, w styczniu 1955 roku. Jeśli pamiętamy, że Hongkong sprzed II wojny światowej był miastem podzielonym rasowo, ta zmiana miała jedno ogromne, historyczne znaczenie: po raz pierwszy w historii Hongkongu przestrzeń w samym jego sercu, miasto elit, przeznaczoną do bycia, siedzenia, patrzenia, rozmawiania udostępniono wszystkim jego mieszkańcom.

Rys. 2. Podział gruntów przed siedzibą Hongkong Bank

(obecnie: Hong Kong and Shanghai Bank, HSBC)

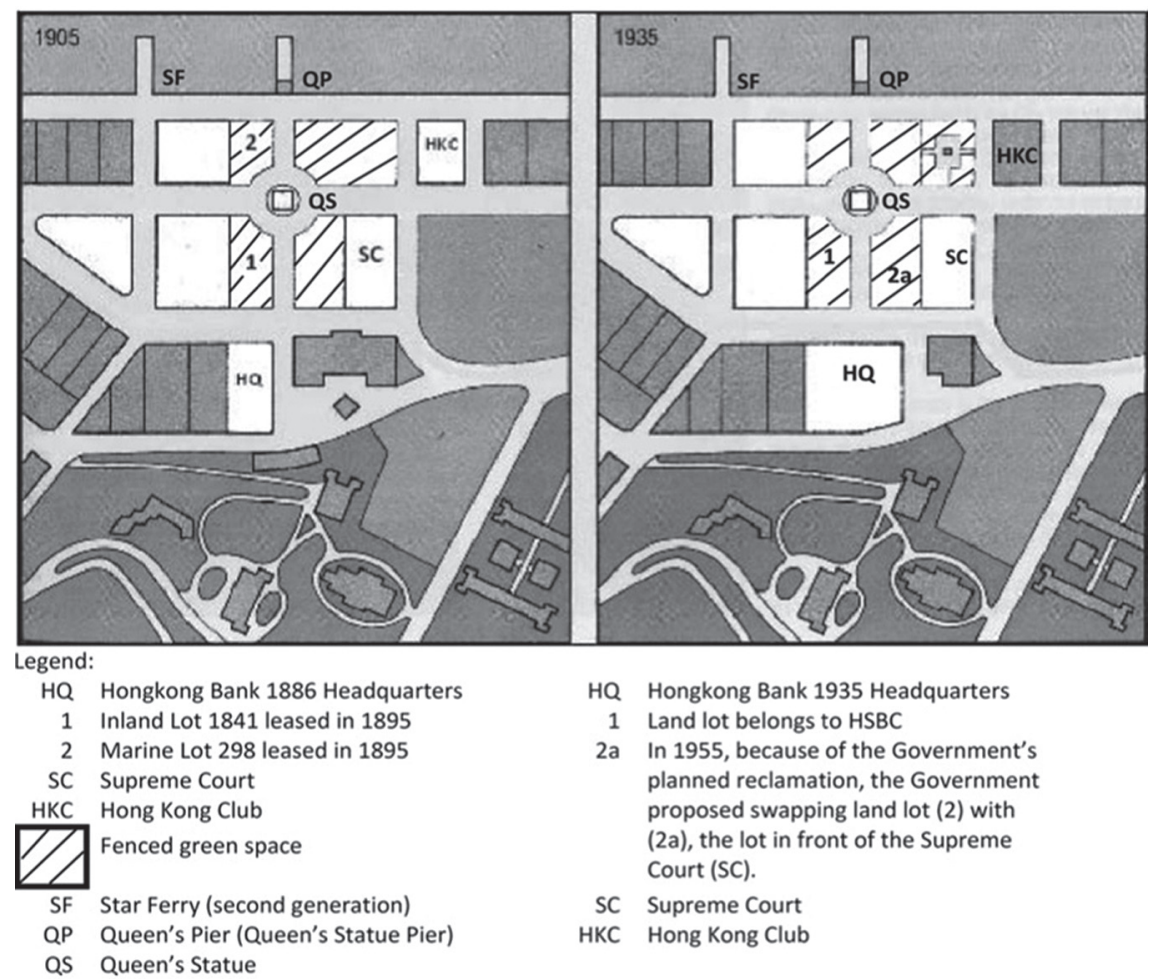

Źródło: M.K. Ng i in., Spatial Practice, Conceived Space and Lived Space: Hong Kong's „Piers Saga” through the Lefeburian Lens, „Planning Perspectives” 2010, Vol. 25, nr 4, s. 412, [online] http://dx.doi.org/10.10 $80 / 02665433.2010 .505060$.

\section{TRANSFORMACJA MIASTA - PRZYSTAŃ JAKO OTWARTA PRZESTRZEŃ PUBLICZNA}

Końcówka lat 50. oraz cała następna dekada to okres bardzo burzliwych zmian zarówno na kontynencie, w Chińskiej Republice Ludowej, jak i w brytyjskim Hongkongu. Sama kwestia uregulowania sprawy Hongkongu była podnoszona kilkakrotnie przez czołowych polityków i przywódców. W 1959 roku przewodniczący Mao Zedong ustalił status quo, mówiąc, że nie należy spieszyć się z odbieraniem Hongkongu Brytyjczykom, dopóki ten 
może być dla Chin użyteczny. Przypieczętowało to rolę Hongkongu jako okna na świat i pośrednika między Zachodem a komunistycznymi Chinami. W 1963 roku po raz pierwszy na łamach czołowego chińskiego dziennika „Renmin Ribao” ukazał się komunikat informujący, że sprawa Hongkongu zostanie rozwiązana na drodze pokojowych negocjacji.

W 1966 roku w Chinach wybucha rewolucja kulturalna, która wprowadziła ten kraj w dekadę chaosu. Rok później pierwsze inspirowane tym wydarzeniem protesty dotarły do Hongkongu. Rozpoczął się okres strajków i zamieszek, który obfitował również w akty terroru. Ostatecznie liczba ofiar śmiertelnych wyniosła 51 osób, rannych zostało około 800 mieszkańców Hongkongu. Ochłodzenie w stosunkach chińsko-rosyjskich wywołało z kolei zbliżenie Chin i Zachodu. Powoli normalizacji ulegały stosunki z krajami zachodnimi. W tym samym czasie w Londynie również zdawano się zauważać potrzebę zmian i koniec epoki kolonializmu. Jeszcze w 1968 roku rząd w Londynie wcielił Colonial Office do Foreign Office. Normalizacja i nawiązanie przez Chiny stosunków dyplomatycznych z krajami zachodnimi stało się formalnością.

Lata 60. to dla ekonomii Hongkongu bardzo ważny okres. Potrzebne było zaprowadzenie porządku i stabilizacja finansów kolonii. Zadanie to przypadło sir Johnowi Cowperthwaite’owi, który przez 10 lat sprawował urząd sekretarza finansów w Hongkongu. Odpowiada on za stworzenie modelu określanego jako hongkońska szkoła ekonomiczna, udało mu się bowiem wypracować model pozytywnej nieinterwencji polityków w sprawy gospodarki. Wpływ industrializacji z tego okresu na tkankę miejską Hongkongu był znaczący.

Lata 60 . były również znaczącym i ważnym okresem, jeżeli chodzi o kształtowanie się nowoczesnych postaw wśród mieszkańców Hongkongu. Poprzednie lata, kiedy Brytyjczycy odbudowywali Hongkong po zniszczeniach wywołanych okupacją japońską w czasie II wojny światowej i próbowali poradzić sobie z masowym napływem imigrantów uciekających do Hongkongu z dopiero co utworzonej Chińskiej Republiki Ludowej na kontynencie, były stosunkowo chaotyczne i burzliwe. Tym większe znaczenia mają pierwsze protesty pod koniec lat 50 . w obrębie nowo powstałej wtedy przestrzeni publicznej. Był to pierwszy krok w kształtowaniu świadomości i własnej tożsamości mieszkańców Hongkongu. Następna dekada i ugruntowanie pozycji Hongkongu jako pośrednika między Chinami a resztą świata oraz kontynuacja polityki płacenia niskich podatków pomogła w kolejnych zmianach wśród mieszkańców. Można powiedzieć, że Hongkong stał się stabilnym i coraz bardziej zamożnym spoteczeństwem w porównaniu z krajami rozwiniętymi w tamtym czasie ${ }^{21}$.

To właśnie wówczas Hongkong zyskał te cechy i postawy, które uważane są za typowo nowoczesne. Oddanie w pomnażaniu kapitału i bogaceniu się pozytywnie odbiło się na gospodarce. Zdaniem Alvina Rabushki Hongkong był w tamtym czasie zaprzeczeniem Wielkiej Brytanii; przyrównywał on Hongkong do „Happy Kingdom” a Wielką Brytanię (United Kingdom) do „Unhappy Kingdom”, z kolei mieszkańca Hongkongu określał mianem homo economicus, co było równoznaczne z homo Hongkongus ${ }^{22}$.

21 F. Welsh, A History of Hong Kong, London 1993, s. 461.

22 Tamże, s. 463. 
Po II wojnie światowej kontynuowano proces odzyskiwania gruntów (rys. 3), jednak baza wojskowa i inne obiekty należące do brytyjskiej marynarki wojennej nadal okupowały znaczny teren nabrzeża na wyspie Hongkong. W latach 1951-1955 udało się również odzyskać 9 akrów na zachód od bazy, w kierunku Sheung Wan, a na Causeway Bay 55 akrów, dzięki czemu powstało miejsce na nową siedzibę władz (City Hall, ukończona w 1962 roku), Główny Urząd Pocztowy (zbudowany w 1976 roku), Jardine House (wcześniej znany pod nazwą Connaught Centre, ukończony w 1973 roku). Ten etap odzyskiwania gruntów był szczególnie ważny z powodu zmiany lokalizacji przystani promowych Star Ferry i Queen's Pier. W związku ze zmianą miejsca oraz przede wszystkim na skutek zmian społecznych po II wojnie światowej przystań Queen’s Pier została udostępniona wszystkim mieszkańcom i szybko stała się ważnym miejscem spotkań.

Rys. 3. Mapa obrazujące kolejne etapy procesu odzyskiwania gruntu na wyspie Hongkong oraz na półwyspie Kowloon od 1946 do 1967 roku

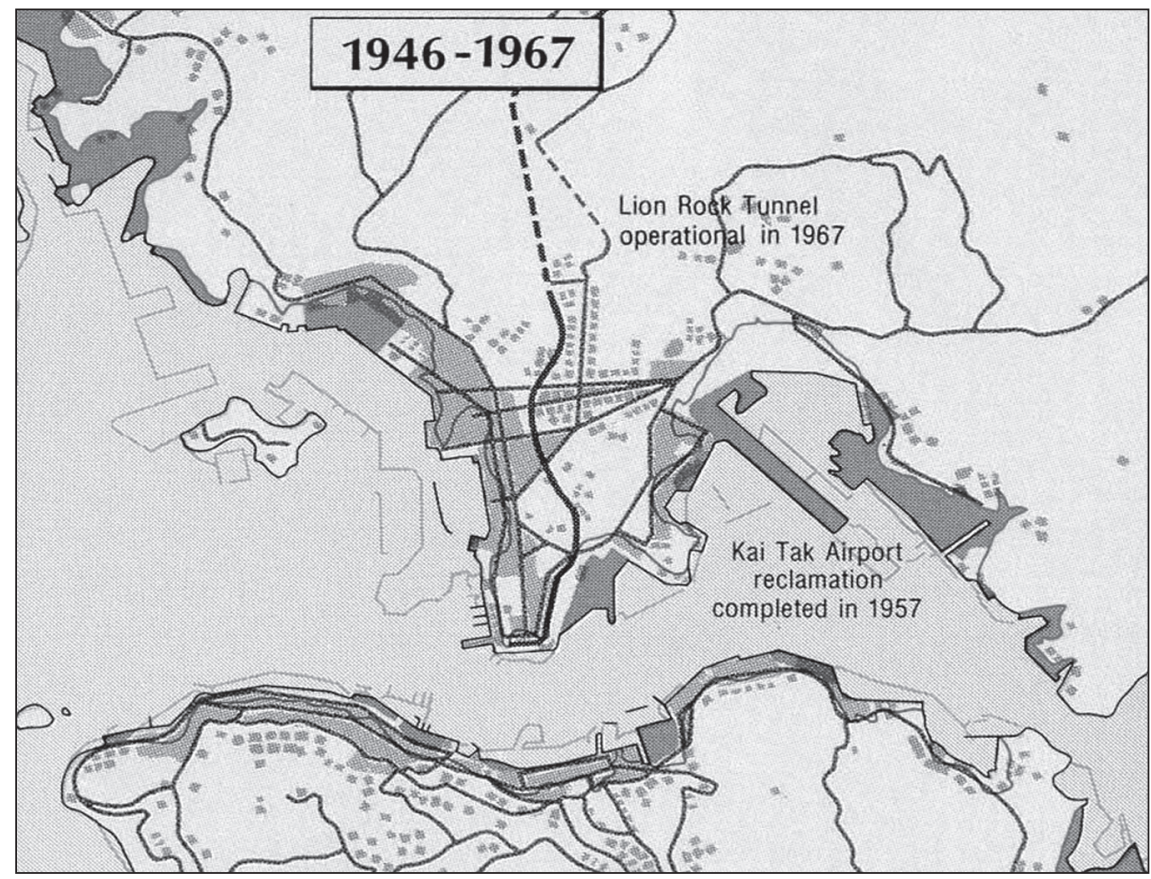

Źródło: Hong Kong Lands Department, Cartography by Survey \& Mapping Office.

Nowa sytuacja polityczna i konieczność odbudowy miasta, a także dalsze odzyskiwanie gruntów wzdłuż nabrzeża sprawiły, że pojawiły się nowe koncepcje zagospodarowania przestrzeni. Najlepiej zmiany te odzwierciedla kolejna już w przypadku przystani Star Ferry oraz pierwsza w przypadku Queen's Pier relokalizacja. Trzecia generacja przystani Star Ferry znajdowała się na zachód od drugiej generacji Queen's Pier, za którym został ulokowany nowy kompleks City Hall, co miało gwarantować odpowiednią oprawę dla nowo przybywających gości korzystających z przystani Queen’s Pier (rys. 4). 
W bezpośrednim otoczeniu kompleksu zaprojektowano i wybudowano miejski ogród, dostępny dla wszystkich mieszkańców, co było ogromną zmianą w porównaniu z poprzednią lokalizacją i bezpośrednim otoczeniem przystani Star Ferry i Queen’s Pier. O wiele ważniejsza jednak była decyzja z 1954 roku, która zmieniała charakter Queen’s Pier z królewskiego i wykorzystywanego wyłącznie do uroczystości oficjalnych na publiczny - dostępny dla wszystkich. Aby jeszcze wzmocnić publiczny charakter tej przestrzeni, w 1957 roku zdecydowano się na umieszczenie tam wieży zegarowej mniejszego bliźniaka londyńskiego Big Bena, z mechanizmem wykonanym przez manufakturę z kilkusetletnim doświadczeniem. W dalszych planach było wybudowanie na zachód od nowej przystani podium łączącego różne usługi, sklepy, restauracje, kina.

Rys. 4. Nowa lokalizacja przystani Star Ferry oraz Queen's Pier wraz z najbliższym otoczeniem i miejskim ogrodem - parkiem zaprojektowanym z myślą o wszystkich mieszkańcach (lata 60. XX wieku)

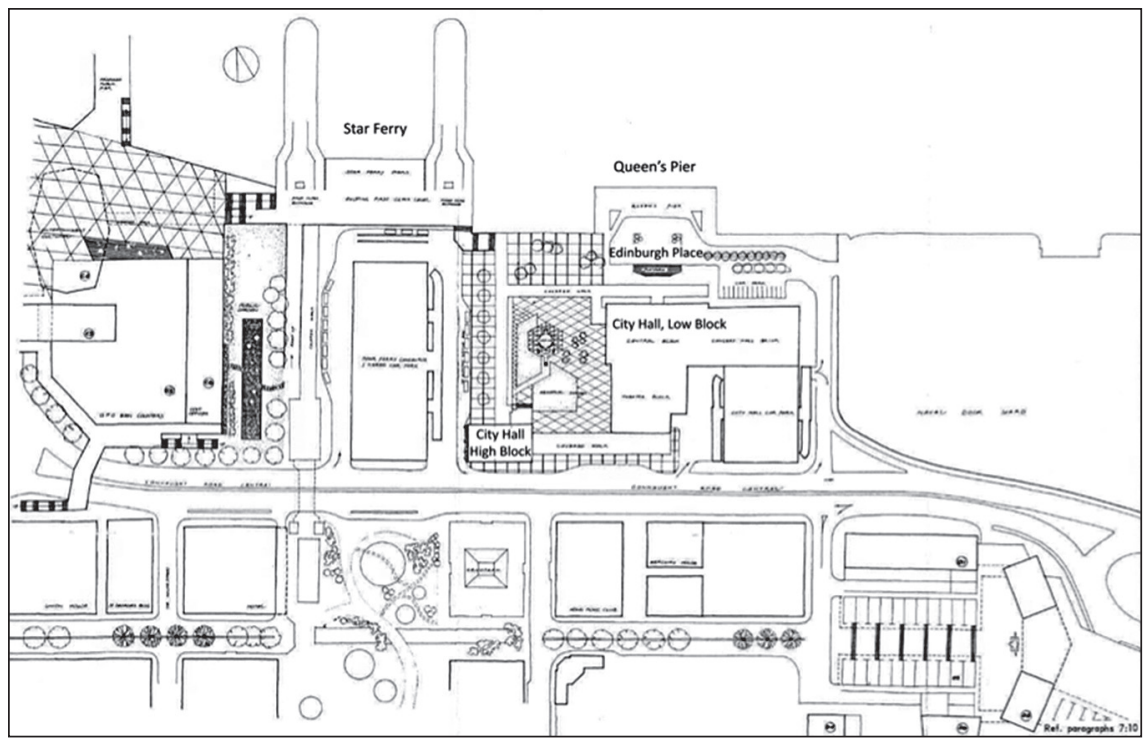

Źródło: Director of Public Works, City of Victoria: Hong Kong Central Area Redevelopment, Hong Kong 1961, s. 30, Fig. 14, za: M.K. Ng i in., Spatial Practice, Conceived Space and Lived Space: Hong Kong's „Piers Saga” through the Lefebvrian Lens, „Planning Perspectives” 2010, Vol. 25, nr 4, s. 421, [online] http:// dx.doi.org/10.1080/02665433.2010.505060.

Widać zatem wyraźnie, że nowa lokalizacja obu przystani była symbolem zmian społecznych. Zmiany te polegały na przekształceniu stosunku władzy kolonialnej do obywateli z elit i zwykłych ludzi na nowoczesny model „rządzących i obywateli”23. Pomimo że obywatelskość mieszkańców Hongkongu pozostaje dosyć spornym

23 LegCo Paper no CB(1)1444/06-07(01), Queen's Pier Is Not Moving Anywhere! Statement of Artists, Cultural Practitioners and Academics in Support of the Preservation of Queen's Pier In Situ, 17 IV 2007, [online] http://www.legco.gov.hk/yr06-07/english/panels/plw/papers/plw0423cb1-1444-1-e.pdf, 24 II 2016. 
zagadnieniem, to bez wątpienia należy podkreślić fakt oddania przestrzeni wszystkim mieszkańcom, a tym samym przyznanie im prawa do własnego miasta, do przebywania w nim, przesiadywania, spacerowania, obserwowania i prowadzenia rozmów w samym centrum (politycznym i ekonomicznym sercu), które jeszcze tak niedawno było kompletnie podzielone.

Relokacja przystani promowych i nadanie im egalitarnego charakteru były dopiero początkiem zmian kontynuowanych w kolejnej dekadzie. Na początku lat 60. XX wieku w rządowym projekcie o nazwie Central Area Redevelopment, dotyczącym dopiero co odzyskanych terenów, władze wskazały na konieczność wykorzystania tej nowo powstałej przestrzeni w celu poprawienia funkcji wspólnotowych, a nie wzmacniania już i tak silnie ugruntowanego procesu komercjalizacji przestrzeni. Przestrzeń wokół przystani oraz ich nowa lokalizacja w latach 50 . XX wieku są symbolem zmian pomiędzy lokalnym rządem a mieszkańcami z relacji „elita-lud” na relację „rząd-obywatele” i ma ogromne znaczenie dla kolonialnej historii Hongkongu ${ }^{24}$.

\section{PRZESTRZEŃ PUBLICZNA A PRAWO DO MIASTA}

Miasto podzielone wąską cieśniną na wyspę Hongkong i półwysep Kowloon miało jeszcze jedną wspólną warstwę spajającą ją w jedną całość - były to dwa pasma wzgórz z najwyższymi wzniesieniami: Wzgórze Wiktorii na wyspie Hongkong $(552 \mathrm{~m})$ oraz Fei Ngo Shan (602 m), które dzieli od siebie odległość w linii prostej wynosząca niewiele ponad $8 \mathrm{~km}$. W latach 50. i 60. ubiegłego wieku wysokość budynków wynosiła średnio $40 \mathrm{~m}$, a te zaliczające się do kategorii najwyższych nie przekraczały $70 \mathrm{~m}$. Stąd owe pasma okalające Hongkong od północy i południa stanowiły naturalne ramy miasta. Podróż pomiędzy obiema częściami Hongkongu była możliwa jedynie dzięki promom - przepłynięcie od jednej przystani na drugi brzeg zabierało w najlepszym razie $8 \mathrm{mi}$ nut. Promy i przystań tworzą istotny element całego miasta, w zasadzie stanowią jego centrum - otoczone z obu stron wzgórzami, które stanowią fizyczną, psychologiczną, a także funkcjonalną krawędź miasta.

Przekraczanie - czy też raczej przepływanie - tej krótkiej odległości doczekało się wielu opisów w literaturze i jest zazwyczaj kojarzone z bardzo pozytywnymi emocjami. Przeżycia związane z odbywaniem podróży promem bywają opisywane jako „niezapomniane”, „spektakularne”, „zapierające dech w piersi”25. Szacuje się, że w 1956 roku każdego dnia odbywało się ponad 750 rejsów promami Star Ferry w obie strony, co ówcześnie stanowiło pomiędzy 10 a 20\% wszystkich podróży publicznymi środkami transportu. Dekadę później było ich odpowiednio 345 plus 939 rejsów odbywających się promami Star Ferry oraz Hongkong \& Yaumatei. W ciągu dwóch dekad udział promów w transporcie publicznym wahał się od 16 do 23\%, stanowiąc istotną część

\section{Tamże.}

25 B. Shelton, J. Karakiewicz, T. Kvan, The Making of Hong Kong from Vertical to Volumetric, LondonNew York 2011, Planning, History and Environment Series, wersja elektroniczna, lok. 1768. 
systemu publicznej komunikacji w mieście. W tym kontekście o wiele łatwiej zrozumieć, dlaczego to właśnie przystań stała się miejscem, gdzie doszło do pierwszych zamieszek i powstania ruchów społecznych w przestrzeni miejskiej Hongkongu.

Incydent, który miał miejsce na przystani Star Ferry w 1966 roku, wywołał zamieszki znane pod nazwą Star Ferry Riots, uznawane przez wielu historyków za początek kształtowania się społeczeństwa obywatelskiego i ruchów społecznych w Hongkon$\mathrm{gu}^{26}$. W tamtym czasie $\mathrm{w}$ proteście przeciwko podniesieniu opłat za korzystanie z promów Star Ferry 27-letni mężczyzna So Sau-chung podjąt indywidualny strajk głodowy. Jego aresztowanie doprowadziło do wybuchu zamieszek na półwyspie Kowloon.

Nastąpiła zupełna zmiana i oddanie przestrzeni mieszkańcom doprowadziło do wykształcenia się poczucia wspólnoty. Zaangażowanie mieszkańców w obronę wspólnych interesów przyczyniło się również w znaczący sposób do budowy fundamentów własnej tożsamości Hongkończyków. Przystań promowa z przestrzeni ekskluzywnej stała się otwarta dla wszystkich mieszkańców, co biorąc pod uwagę ich trudne warunki życia i minimalną przestrzeń, jaka przypadała na jedną osobę w większości mieszkań oferowanych w Hongkongu, miało duże znaczenie dla formowania się poczucia wspólnoty. Zamieszki wokół przystani Star Ferry należy również rozumieć w szerszym kontekście zmian i pogorszenia warunków życia społecznego, począwszy od lat 50.

Skutkiem tych protestów była fundamentalna zmiana polityki kolonialnego rządu wobec mieszkańców i miasta. Przede wszystkim utworzono schemat „miasto-dystrykt-urzędnik", który miał przybliżyć rząd do mieszkańców i ich problemów. Wprowadzono również zmiany w dziedzinach: edukacji, pracy, dostępu do służby zdrowia, opieki socjalnej, ochrony przyrody oraz, co ze względu na nieustanny niedobór mieszkań stanowiło najważniejszy punkt reform, 10-letni program mieszkaniowy połączony z rozwojem i budową nowych miast na półwyspie Kowloon.

Jak słusznie zauważają niektórzy badacze, nowa polityka rządu kolonialnego dała impuls zazwyczaj biernemu i apatycznemu w kwestiach politycznych społeczeństwu wychowanemu na wartościach konfucjańskich do bardziej aktywnej postawy, szczególnie wśród młodej generacji ${ }^{27}$. Częsść z nich nie chciała już podążać śladami rodziców i pozostawać $\mathrm{w}$ cieniu, nie protestując, wręcz przeciwnie - chcieli brać aktywny udział w życiu społecznym, domagając się swoich obywatelskich praw. Powstały stowarzyszenia: Dziedzictwa Społecznego, Stowarzyszenie Konserwacji, Obserwatorzy Hongkongu, Grupa Aktywna Edukacja oraz Związek Nauczycieli. Dzięki strategicznej lokalizacji - sam środek miasta - przystań Star Ferry szybko stała się centralnym punktem zebrań wielu tych organizacji i związków. Podobnie druga przystań, Queen's Pier, która również stała się popularnym miejscem różnych aktywności społecznych - wliczając w to

26 P.S.S. Chan, A Survey Report of Historical Buildings and Structures within the Project Area of the Central Reclamation Phase III, The Antiquities and Museums Office, Leisure and Cultural Service Department, 2001, [online] http://www.epd.gov.hk/eia/register/report/eiareport/eia_0552001/report/ vol2/eia_0552001appendix_w.pdf, 27 X 2016.

27 M.K. Ng i in., Spatial Practice, Conceived Space and Lived Space: Hong Kong's „Piers Saga” through the Lefeburian Lens, „Planning Perspectives” 2010, Vol. 25, nr 4, s. 422, [online] http://dx.doi.org/10.10 80/02665433.2010.505060. 
słynne zawody pływackie w przepłynięciu portu na dystansie dzielącym wyspę Hongkong od półwyspu Kowloon. Było to również miejsce kampanii na rzecz wprowadzenia języka chińskiego jako urzędowego oraz ruchu obrony wysp Diaoyu w 1970 roku. Dogodna przestrzeń w pobliżu obu przystani nie tylko symbolizowała możliwość przebywania w przestrzeni wraz z innymi ludźmi. Ta przestrzeń dała nowej generacji dostęp do samego serca miasta, który był im odmawiany w wiktoriańskim Hongkongu.

\section{LOSY PRZYSTANI PO 1997 ROKU A PRÓBA ZDEFINIOWANIA WŁASNEJ TOŻSAMOŚCI HONGKONGU}

Po 1997 roku Legislative Council (LegCo) - parlament SRA Hongkong - w porozumieniu z Pekinem próbuje używać historii i dziedzictwa w celu zachowania poczucia lokalności Hongkongu w zgodzie z koncepcja szerszego znaczenia chińskiego nacjonalizmu. Kilka nowych muzeów prowadzonych przez Departament Kultury poświęcono lokalnej historii, utworzono Muzeum Sun Jat-sena oraz Historyczny Szlak Sun Jat-sena, aby podkreślić wkład Hongkongu w rozwój chińskiego nacjonalizmu. Więcej rdzennych świątyń i wiosek na Nowych Terytoriach zostało wymienionych jako miejsca dziedzictwa kulturowego, by z kolei podkreślić prekolonialną historię Hongkongu jako części Chin kontynentalnych. Tymczasem gdy LegCo starał się podkreślić oryginalny chiński charakter Hongkongu, zamiast hybrydyczności Wschód-Zachód, która zdefiniowała granice współczesnego Hongkongu, wielu mieszkańców zdecydowało się doceniać swoje mieszane tożsamości, wyrażane w tradycji i architekturze, które definiowały ich historyczną odrębność od Chin kontynentalnych. Taka sytuacja ostatecznie prowadzi do paradoksu Chińczyków z Hongkongu broniących brytyjskich symboli epoki kolonialnej, by wyrazić tym samym swoją własną lokalną tożsamość będącą w opozycji do koncepcji chińskiego nacjonalizmu propagowanego przez Pekin.

Współczesny konflikt o przystań rozgrywa się w oparciu o kolejny projekt zyskiwania nowych ziem, w związku z czym Queen’s Pier został w 2008 roku usunięty, co z kolei doprowadziło do ogromnych protestów samych mieszkańców miasta. Jak pisze jeden z dziennikarzy SCMP Alex Lo: Poprzednia przystań Queen's Pier zajmowata wyjątkowe miejsce w zbiorowej pamięci mieszkańców Hongkongu. [...] Przez dekady przystań, wraz z Edinburgh Place i Ratuszem, petnity funkcje gtównego placu publicznego, tworząc węzet dla transportu przez cieśninę oraz centralna częśc, w petni dostosowana do najważniejszych wydarzeń kulturalnych. Byto to miejsce spotkań dla przyjaciót, rodziny $i$ kochanków. Kazdy brytyjski gubernator przybywat i opuszczat kolonięna przystani. Byta ona fizycznym ucieleśnieniem naszej historii i kultury ${ }^{28}$. W wyniku pięciu kolejnych faz odzyskiwania nowych terytoriów na północnym wybrzeżu wyspy Hongkong w dzielnicach Wan Chai i Central doprowadzono do zmiany wyglądu wybrzeża. W procesie tym możemy wyróżnić następujące etapy:

28 A. Lo, Hong Kong Has a Golden Chance to Restore Queen's Pier to its Former Glory, „South China Morning Post" 2016, 27 IV, [online] http://www.scmp.com/comment/insight-opinion/article/1939403/ hong-kong-has-golden-chance-restore-queens-pier-its-former, 30 XII 2016. 
1. Wanchai Reclamation Phase I - miała na celu utworzenie gruntu pod budowę The Hong Kong Convention and Exhibition Centre Extension. Ukończona w 1997 roku.

2. Wanchai Development Phase II - objęła 12,7 ha (z początkowo planowanych 28,5 ha), miała na celu utworzenie drogi i połączenia ze Wschodnim Korytarzem prowadzącym do tunelu pod cieśniną, łączącego wyspę z półwyspem Kowloon. W planach jest również utworzenie przybrzeżnej promenady dla mieszkańców.

3. Central Reclamation Phase I - 20 ha pod trakcję kolejową i stację MTR Hongkong oraz przedłużenie i rozbudowa dzielnicy biznesowej. Ukończona w 1998 roku.

4. Central Reclamation Phase II - 5,3 ha dla utworzenia otwartej przestrzeni publicznej i rozwój centrum komercyjnego w pobliżu Tamar Basin, ukończona we wrześniu 1997 roku.

5. Central Reclamation Phase III - ostatnia faza odzyskiwania gruntu miała na celu odzyskanie terenów pod budowę tzw. obwodnicy Central-Wan Chai Bypass oraz budowę czteropasmowej drogi tzw. P2. W planach była również rozbudowa i przedłużenie istniejącego tunelu prowadzącego na lotnisko, a także miejsca postoju dla statków Armii Ludowo-Wyzwoleńczej. Ostatecznie z planowanych początkowo 32 ha zmniejszono plany do odzyskania zaledwie 18 ha z uwagi na spore zastrzeżenia co do skali planowanych inwestycji ${ }^{29}$.

Central Reclamation Phase III (CR III), czyli ostatnia faza odzyskiwania ziemi, wymagała rozbiórki przystani promów Star Ferry i Queen’s Pier, który musiał ustąpić miejsca drodze P2, kolei na lotnisko oraz poszerzonemu wyjściu z tunelu. Zgodnie z priorytetami tej fazy i brakiem polityki, która byłaby zorientowana na historyczną ochronę założeń urbanistycznych, parlament LegCo uznał za istotniejszy rozwój infrastruktury transportowej. Central-Wan Chai Bypass (CWB) zwiazany z siecia dróg P2 zapewni pilna pomoc $w$ roztadowaniu korków $w$ dzielnicy Central, a nawet $w$ catym pótnocnym brzegu wyspy Hongkong - tak brzmiało nadrzędne uzasadnienie podane przez różne departamenty rządowe w ramach projektu. Typowy komunikat ostrzegający brzmiał natomiast: Jeśli CWB nie będa gotowe w 2011/2012, tunel będzie obstugiwat natężenie ruchu o 30 proc. powyżej swojej maksymalnej pojemności, czas podróży pogorszy do 45 minut, a średnia prędkość pojazdu będzie dochodzita do $5 \mathrm{~km} / \mathrm{h}^{30}$. Budowa drogi P2 jest konieczna, ponieważ natężenie ruchu na drogach w dzielnicy centralnej jest już krytyczne i jeśli zatory nadal będa się pogarszać, to wptynie to poważnie na dziatanie Exchange Square, dworca na wyspie Hongkong (Airport Express/Tung Chung Line), IFC, inwestycji hotelowych, przystani promowych i innych wydarzeń komercyjnych w okolicy. Bez drogi P2 ruch w obszarze bytby sparaliżowany w 2011 roku, niszczac wydajność Centralnej

29 Legislative Council, Background brief on Central and Wanchai reclamation, LC Paper No. CB(1) 18/03-04(01), [online] http://www.legco.gov.hk/yr03-04/english/panels/plw/papers/eaplw1013cb1-18-1e.pdf, 30 XII 2016.

30 Development Bureau - Planning and Lands Branch - Publications and Press Releases, [online] http://archive.is/www.devb-plb.gov.hk, 30 XII 2016. 
Dzielnicy Biznesowej, zmniejszając tym samym jej atrakcyjność dla inwestorów i pociagajac za soba znaczne straty gospodarcze.

Widać zatem wyraźnie, że oficjalna debata rządzących Hongkongiem zdominowana była przez dyskurs „czas to pieniądz” i presję stworzenia nowej infrastruktury. Zagadnienia związane z ochroną środowiska, takie jak jakość powietrza, kwestie estetyczne oraz sprawa konserwacji zabytków historycznych były wątkiem pobocznym, słabo akcentowanym w całej dyskusji. Stąd też kiedy w 2006 roku parlament LegCo ogłosił, że CR III poddane zostało wieloletnim konsultacjom społecznym i projekt został zatwierdzony na wszystkich etapach planowania przestrzennego, wywołał tym szok wśród mieszkańców, gdyż ważne dla nich sprawy zostały w zasadzie nieporuszone. Jeden z aktywistów broniących przystani, Chu Hoi-dick, stwierdzil, że rząd chciał zdewaluować znaczenie wyburzenia przystani, koncentrując się na pilnej potrzebie rozbudowy infrastruktury wokół CWB. Wszystko, co wykraczało poza tę kwestię, było negowane"31. Warto również dodać, że rząd pomijał słowa „rozbiórka” i „wyburzyć”, zamiast tego używano słów: „relokacja” i „odtworzenie” ${ }^{2}$. Dopiero gdy w grudniu 2006 roku runęła wieża zegarowa przystani Star Ferry, stało się oczywiste, co dla parlamentu LegCo $\mathrm{w}$ istocie oznaczał oficjalny dyskurs.

Najbardziej aktywnym stowarzyszeniem broniącym przystani była Społeczność Ochrony Wybrzeża (Society for the Protection of the Harbour), która organizowała protesty i wnosiła sprawy do sądu przeciwko działaniom rządu zmierzającym do wyburzenia przystani. Dnia 21 marca 2004 roku na manifestację przyszło aż 20 tys. mieszkańców, którzy trzymając się za ręce, stworzyli żywy łańcuch wzdłuż wybrzeża od Edinburgh Place do The Convention and Exhibition Centre. Organizacje pozarządowe wspólnie organizowały akcje protestacyjne i informacyjne. Do obrony przystani przystąpili również dziennikarze, w prasie ukazywały się artykuły o historii i znaczeniu obu przystani, organizowano warsztaty i spotkania dla mieszkańców. Wszystkie te działania poskutkowały pojawieniem się 150 tys. mieszkańców w ostatnim dniu kursowania promów z przystani Star Ferry, w dniu 11 listopada 2006 roku. Protesty o znacznie mniejszej skali trwały aż do 13 grudnia, kiedy to doszło do starć z policją i okupujący przystań Star Ferry zostali z niej siłą usunięci. Dzień później 200 osób przemaszerowało, by uczcić 49. rocznicę budowy częściowo już wyburzonej przystani. Sto osób próbowało wejść na teren przy przystani, policja aresztowała trzynaście osób. Dnia 16 grudnia wyburzono wieżę zegarową. Przystanie zostały rozebrane na części i złożone w magazynach, w oczekiwaniu na decyzję władz.

W ostatnich miesiącach powrócił temat Queen's Pier, okazało się bowiem, że lokalizacja przystani w jej historycznym miejscu, do którego była przyporządkowana, czyli w samym sercu miasta, jest koncepcją znacznie tańszą od pozostałych, zakładających jej przeniesienie i odrestaurowanie na którejś z odleglejszych wysp. Ostatecznej decyzji wciąż brakuje, nietrudno jednak się domyślić, że monitorowany przez Pekin rząd

31 K. Chai, Central Star Ferry Pier: Policy, Politics and Protest in the Making of Heritage in Hong Kong, Postgraduate Thesis, The University of Hong Kong, 2009, s. 27, [online] http://dx.doi.org/10.5353/ th_b4758135, 31 I 2017.

32 Tamże, s. 28. 
będzie chciał pozbyć się przystani, która w sposób symboliczny przypomina o prawach mieszkańców do miasta i przestrzeni. Przestrzeń wokół przystani znalazła się w środku konfliktu pomiędzy tym, co mieszkańcy uważają za ważne i istotne dla swojej historii i co stanowi o ich odrębności, a nowymi władzami budującymi swój własny porządek. $W$ centrum uwagi pozostaje tu wymiar symboliczny transformacji - wprowadzenie do wyobraźni zbiorowej nowego lub odzyskiwanego na nowo porządku zdarzeń, które określa, czym jest rzeczywistość i co jest dla niej ważne $e^{33}$.

\section{WNIOSKI}

Historia przystani promów na wyspie Hongkong, w jego samym sercu, bardzo wyraźnie odzwierciedla zmiany społeczne i ukazuje poszczególne zwroty i momenty przełomowe w kształtowaniu się tożsamości mieszkańców tego miasta. Przystanie, które dawniej stanowiły fizyczną granicę miasta, i promy stamtąd odpływające, będące jedynym środkiem umożliwiającym przedostanie się na kontynent, zajmują bardzo ważne miejsce w pamięci zbiorowej. W pewnym symbolicznym sensie nadal są granicą pomiędzy dwoma światami. Demontaż Queen’s Pier i brak jasnych decyzji władz Hongkongu w sprawie ewentualnej rekonstrukcji przystani raczej nie spowodują zatarcia się tej symbolicznej bariery, czego dowodem są protesty mieszkańców przeciwko działaniom władz. Przestrzeń ta jest i pozostanie jednak przedmiotem sporu z uwagi na swoje niedopasowanie i brak legitymizacji dla obecnego „znaczącego innego” - Chin kontynentalnych. Zrozumiałe jest, że w takiej sytuacji Pekin wymusza wyburzanie czy też demontaż poprzednich symboli i zastępuje je pustką albo wprowadza nowe formy legitymizujące własną pozycję, czego przykładem może być projekt Muzeum Historii Chin, który został ogłoszony w ostatnich tygodniach. Historia przystani promowych w Hongkongu stanowi zatem odzwierciedlenie procesów kształtowania się lokalnej tożsamości mieszkańców, budowanej w opozycji do „znaczącego innego”, a także negocjowanej z fizycznymi barierami wynikającymi z położenia geograficznego i ukształtowania terenu, na którym położony jest Hongkong.

\section{BIBLIOGRAFIA}

Abbas A., Hong Kong. Culture and the Politics of Disappearance, Minneapolis 1997, Public Worlds, 2.

Agrest D.I., Architecture from Without. Theoretical Framings for a Critical Practice, Cambridge (Mass.) 1993.

Bokszański Z., Tożsamości zbiorowe, Warszawa 2005.

Castells M., Spoteczeństwo sieci, przeł. M. Marody i in., red. nauk. tenże, Warszawa 2008, Wiek Informacji, 1.

33 E. Hałas, Symbole w interakcji, Warszawa 2001, s. 318. 
Chai K., Central Star Ferry Pier: Policy, Politics and Protest in the Making of Heritage in Hong Kong, Postgraduate Thesis, The University of Hong Kong, 2009, [online] http://dx.doi. org/10.5353/th_b4758135.

Chan P.S.S., A Survey Report of Historical Buildings and Structures within the Project Area of the Central Reclamation Phase III, The Antiquities and Museums Office, Leisure and Cultural Service Department, 2001, [online] http://www.epd.gov.hk/eia/register/report/eiareport/ eia_0552001/report/vol2/eia_0552001appendix_w.pdf.

Development Bureau - Planning and Lands Branch - Publications and Press Releases, [online] http://archive.is/www.devb-plb.gov.hk.

Ethnic Groups and Boundaries. The Social Organization of Culture Difference, ed. F. Barth, Illinois 1969.

Hałas E., Symbole w interakcji, Warszawa 2001.

Jałowiecki B., Spoteczne wytwarzanie przestrzeni, Warszawa 1988.

Jelonek A.W., Wielokulturowość, separatyzm i budowa państwa narodowego w Tajlandii, Kraków 2011.

LegCo Paper no CB(1)1444/06-07(01), Queen's Pier Is Not Moving Anywhere! Statement of Artists, Cultural Practitioners and Academics in Support of the Preservation of Queen's Pier In Situ, 17 IV 2007, [online] http://www.legco.gov.hk/yr06-07/english/panels/plw/papers/ plw0423cb1-1444-1-e.pdf.

Legislative Council, Background brief on Central and Wanchai reclamation, LC Paper No. CB(1) 18/03-04(01), [online] http://www.legco.gov.hk/yr03-04/english/panels/plw/papers/eaplw1013cb1-18-1e.pdf.

Lo A., Hong Kong Has a Golden Chance to Restore Queen's Pier to its Former Glory, „South China Morning Post” 2016, 27 IV, [online] http://www.scmp.com/comment/insight-opinion/ article/1939403/hong-kong-has-golden-chance-restore-queens-pier-its-former.

McDonogh G., Wong C., Global Hong Kong, New York-London 2005.

Ng M.K. i in., Spatial Practice, Conceived Space and Lived Space: Hong Kong's „Piers Saga” through the Lefebvrian Lens, „Planning Perspectives” 2010, Vol. 25, nr 4, [online] http://dx.doi. org/10.1080/02665433.2010.505060.

O Krakowie raz jeszcze. Szkice do portretu miasta, red. K. Frysztacki, Z. Mach, Kraków 2008.

Shelton B., Karakiewicz J., Kvan T., The Making of Hong Kong from Vertical to Volumetric, London-New York 2011, Planning, History and Environment Series.

Szczepański M., „Miasto socjalistyczne” i świat spoteczny jego mieszkańców, Warszawa 1991, Rozwój Regionalny, Rozwój Lokalny, Samorząd Terytorialny, 32.

Turner J.C., Oakes P.J., The Significance of the Social Identity Concept for Social Psychology with Reference to Individualism, Interactionism and Social Influence, „British Journal of Social Psychology” 1986 Vol. 25, nr 3, [online] http://dx.doi.org/10.1111/j.2044-8309.1986. tb00732.x.

Turner M., 60s/90s, Hong Kong Sixties. Designing Identity, red. tenże, I. Ngan, Hong Kong 1996.

Virilio P., Lost Dimension, New York 1991, Semiotext(e) Foreign Agents Series.

Walker A., Hong Kong. The Contractors' Experience, Hong Kong 1995.

Wallis A., Socjologia wielkiego miasta, Warszawa 1967, Omega, 69. 
Welsh F., A History of Hong Kong, London 1993.

Znaniecki F., Socjologiczne podstawy ekonomii ludzkiej, „Ruch Prawniczy, Ekonomiczny i Socjologiczny" 1938, nr 1.

Zukin S., Postmodern Urban Landscapes: Mapping Culture and Power, [w:] Modernity and Identity, red. S. Lash, J. Friedman, Oxford 1992.

Mgr Małgorzata OSIŃSKA - doktorantka na Wydziale Studiów Międzynarodowych i Politycznych Uniwersytetu Jagiellońskiego. Stypendystka Ministerstwa Nauki i Szkolnictwa Wyższego RP na Yunnan University w Kunmingu, Chiny (2009-2010), stypendystka Ministerstwa Edukacji ChRL (CSC) na Zhejiang University w Hangzhou, Chiny (2011-2017). Otrzymała trzymiesięczny grant na Hongkong Polytechnic University, Department of Applied Social Science w ramach programu prowadzenia badań dla doktorantów (2015). Jej zainteresowania koncentrują się na interdyscyplinarnych badaniach problemów współczesnych miast oraz związkach przestrzeni z procesami kształtowania się lokalnych tożsamości i zmianami społecznymi. 